\title{
PROTOTYPE OF WATER PIPE LEAKAGE DETECTOR USING FLOWMETER SENSOR BASED ON ARDUINO UNO
}

\author{
Parama Diptya Widayaka*, Lutfi Jauhari \\ Department of Electrical Engineering \\ University of PGRI Adi Buana Surabaya \\ *Corresponding email address: diptyawidayaka@unipasby.ac.id
}

\begin{abstract}
Water pipe leakage causes financial loss for the user such as PAM or PDAM. YF-S201B flowmeter sensor is a water flow sensor made of plastic with a rotor and hall effect sensor inside. The rotor will spin when the water flow through the sensor. The speed of rotor spin is proportional to the water flow. The hall effect based sensor can be used to detect water flow up to 30 liter/minute $(1.800 \mathrm{~L} / \mathrm{hour})$ thus, the sensor can be used to control the water flow in distribution system and water debit monitoring. The principle of prototype is the placement of sensor before the leakage and after leakage position to obtain different value of water debit. The system will send a short message automatically to the phone if water leakage is detected in the pipeline.
\end{abstract}

Keywords: flowmeter sensor, YF-S201B, water pipe leakage detection, Arduino Uno

\section{INTRODUCTION}

Water pipe leakage causes financial loss for the user such as PAM (Drinking Water Company) or PDAM (Local Drinking Water Company) [1]. According to released news from Kompasiana.com, 12 September 2014, water pipe leakage usually caused by technical leakage and non-technical leakage [2]. Technical leakage is a kind of leakage caused by pipe leakage and other equipment. Non-technical leakage is a leakage caused by water theft, illegal distribution connection, and low-accuracy measurement tools [3]. In the water pipe leakage detection, PDAM usually use conventional system by manually monitor if there is puddle on water pipe or by collecting report from people about water pipe leakage. This kind of method need more time because water pipe line has big and complex areas [4]. According to the problem, the prototype of water leakage detector using flow meter sensor based on Arduino Uno is proposed by installing the water flow sensor in the input and output of the water pipe line. The goal of the system because of some expectation to optimize and simplify in water pipe leakage detection, knowing the water debit that comes out from the pipe to know the losses, and time efficiency.

\section{RESEARCH METHODS}

Water leakage causes pipeline corrosion, material defects, unstable water pressure, installation errors and so on [5]. This research discusses about a system which can detect water leakage through water pipe to optimize the work of water distribution and monitor the water distribution. Two water flow sensors installed to recognize constant water leakage. The rotor rolls when water flows through the rotor [6]. In the proposed methods, the system uses some devices such as water flow sensor to detect water flow through the pipeline, Arduino Uno as the main microcontroller to processes the data, and SIM800L to send a short message to the phone. To collect data for this research, there are some steps to evaluate the prototype as follow:

1. Water pump and water pipe experiments.

2. Hardware and software experiments.

3. SIM800L GSM Module and Arduino connectivity experiments.

4. Send short message if water leak occurred.

The system block diagram can be shown in Figure 1. 
BEST

Journal of Applied Electrical \& Science Technology - University of PGRI Adi Buana

p-ISSN 2715-2871

e-ISSN 2714-5247

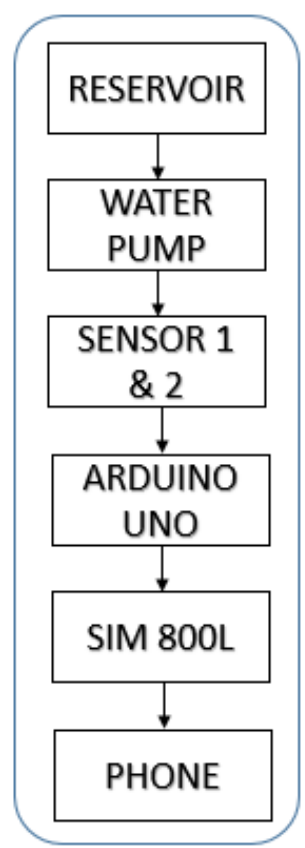

Figure 1. System Block Diagram

From the block diagram in Figure 1, water pump will pump the water from the reservoir through the pipe which connected to water flow sensor. Water flow sensor will read the water flow speed to obtain the difference between sensor 1 and sensor 2 , if there are some differences data reading from the sensor, the Arduino will send a message to the phone through SIM 800L to give notification to the operator if water leak occurred.

\section{RESULTS AND DISCUSSION}

This part discusses about the results of the prototype experiments to detect water leak through the pipe using water flow sensor YFS201B based on Arduino Uno. The experiment is start from collecting data from each sensor which connected to the pipe and the last testing the system of the prototype.

\section{Water Flow Sensor 1 and sensor 2 Experiment Result}

From the experiment of water flow sensor 1 given the result of sensor reading experiment which present in table 1 . The sensor reading experiment take sampling time for 10 second each sensor.

Table 1. Experiment result sensor 1

\begin{tabular}{|c|c|c|}
\hline Time & Water debit & Volume \\
\hline $13: 08: 52.755$ & $24 \mathrm{~L} / \mathrm{min}$ & $820 \mathrm{~mL}$ \\
\hline
\end{tabular}

\begin{tabular}{|l|l|l|}
\hline $13: 08: 53.739$ & $24 \mathrm{~L} / \mathrm{min}$ & $1227 \mathrm{~mL}$ \\
\hline $13: 08: 54.771$ & $24 \mathrm{~L} / \mathrm{min}$ & $1634 \mathrm{~mL}$ \\
\hline $13: 08: 55.755$ & $24 \mathrm{~L} / \mathrm{min}$ & $2041 \mathrm{~mL}$ \\
\hline $13: 08: 56.739$ & $24 \mathrm{~L} / \mathrm{min}$ & $2451 \mathrm{~mL}$ \\
\hline $13: 08: 57.770$ & $24 \mathrm{~L} / \mathrm{min}$ & $2858 \mathrm{~mL}$ \\
\hline $13: 08: 58.755$ & $24 \mathrm{~L} / \mathrm{min}$ & $3268 \mathrm{~mL}$ \\
\hline $13: 08: 59.739$ & $24 \mathrm{~L} / \mathrm{min}$ & $3675 \mathrm{~mL}$ \\
\hline $13: 09: 00.770$ & $24 \mathrm{~L} / \mathrm{min}$ & $4082 \mathrm{~mL}$ \\
\hline $13: 09: 01.754$ & $24 \mathrm{~L} / \mathrm{min}$ & $4492 \mathrm{~mL}$ \\
\hline
\end{tabular}

Experiment of water flow sensor 2 given the result of sensor reading experiment which present in table 2. The sensor reading experiment take sampling time for 10 second each sensor.

Table 2. Experiment result sensor 2

\begin{tabular}{|c|c|c|}
\hline Time & Water debit & Volume \\
\hline $13: 12: 00.025$ & $24 \mathrm{~L} / \mathrm{min}$ & $818 \mathrm{~mL}$ \\
\hline $13: 12: 01.017$ & $24 \mathrm{~L} / \mathrm{min}$ & $1223 \mathrm{~mL}$ \\
\hline $13: 12: 02.028$ & $24 \mathrm{~L} / \mathrm{min}$ & $1629 \mathrm{~mL}$ \\
\hline $13: 12: 03.042$ & $24 \mathrm{~L} / \mathrm{min}$ & $2035 \mathrm{~mL}$ \\
\hline $13: 12: 04.015$ & $24 \mathrm{~L} / \mathrm{min}$ & $2446 \mathrm{~mL}$ \\
\hline $13: 12: 05.063$ & $24 \mathrm{~L} / \mathrm{min}$ & $2852 \mathrm{~mL}$ \\
\hline $13: 12: 06.059$ & $24 \mathrm{~L} / \mathrm{min}$ & $3258 \mathrm{~mL}$ \\
\hline $13: 12: 07.039$ & $24 \mathrm{~L} / \mathrm{min}$ & $3663 \mathrm{~mL}$ \\
\hline $13: 12: 08.038$ & $24 \mathrm{~L} / \mathrm{min}$ & $4070 \mathrm{~mL}$ \\
\hline $13: 12: 09.060$ & $24 \mathrm{~L} / \mathrm{min}$ & $4478 \mathrm{~mL}$ \\
\hline
\end{tabular}

From the water flow sensor experiments that presented in the table above, all of sensors work properly without significantly problems. The sensors can be used in the next experiment to test water leak from the pipe that has been designed before that can be seen in figure 2 .

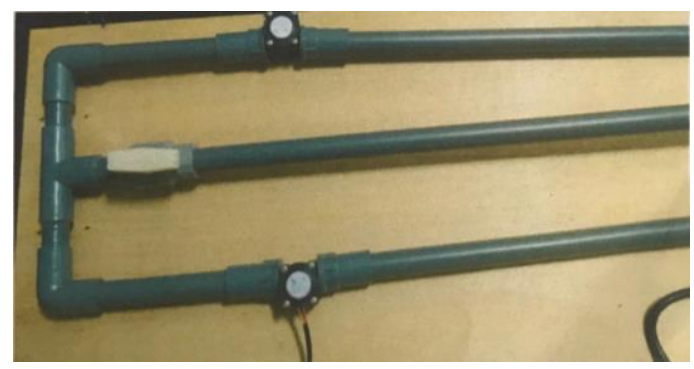

Figure 2. Water Leak Pipeline Design 
BEST

Journal of Applied Electrical \& Science Technology - University of PGRI Adi Buana

As can be seen in Figure 2, there are three lines of pipes which top and bottom pipe connected to water flow sensor meanwhile middle pipe connected to water faucet to simulate the water leak.

\section{Water Leakage Experiment Results}

In this chapter present the experiment result from the water leakage system by using two sensors simultaneously where, water flow sensor 1 calculate the water debit input before water leak point and water flow sensor 2 is placed after the water leak point to calculate the water debit output. There are several steps to test the water leakage detection system as follows:

\section{A. Water leakage detection experiment without water leak}

The first experiment by setting the water faucet in the closed position so, there is no water leak occurred in the pipelines during water flow inside the pipes. The experiment results can be seen in table 3.

Table 3. Water flow experiment without water leak

\begin{tabular}{|c|c|c|c|}
\hline \multicolumn{2}{|c|}{ Sensor 1 (In) } & \multicolumn{2}{c|}{ Sensor 2 (Out) } \\
\hline $\begin{array}{c}\text { Water } \\
\text { Debit }\end{array}$ & Volume & $\begin{array}{c}\text { Water } \\
\text { Debit }\end{array}$ & Volume \\
\hline $21 \mathrm{~L} / \mathrm{min}$ & $362 \mathrm{~mL}$ & $21 \mathrm{~L} / \mathrm{min}$ & $362 \mathrm{~mL}$ \\
\hline $21 \mathrm{~L} / \mathrm{min}$ & $724 \mathrm{~mL}$ & $21 \mathrm{~L} / \mathrm{min}$ & $724 \mathrm{~mL}$ \\
\hline $21 \mathrm{~L} / \mathrm{min}$ & $1086 \mathrm{~mL}$ & $21 \mathrm{~L} / \mathrm{min}$ & $1086 \mathrm{~mL}$ \\
\hline $21 \mathrm{~L} / \mathrm{min}$ & $1448 \mathrm{~mL}$ & $21 \mathrm{~L} / \mathrm{min}$ & $1448 \mathrm{~mL}$ \\
\hline $21 \mathrm{~L} / \mathrm{min}$ & $1810 \mathrm{~mL}$ & $21 \mathrm{~L} / \mathrm{min}$ & $1810 \mathrm{~mL}$ \\
\hline $21 \mathrm{~L} / \mathrm{min}$ & $2172 \mathrm{~mL}$ & $21 \mathrm{~L} / \mathrm{min}$ & $2168 \mathrm{~mL}$ \\
\hline $21 \mathrm{~L} / \mathrm{min}$ & $2530 \mathrm{~mL}$ & $21 \mathrm{~L} / \mathrm{min}$ & $2526 \mathrm{~mL}$ \\
\hline $21 \mathrm{~L} / \mathrm{min}$ & $2888 \mathrm{~mL}$ & $21 \mathrm{~L} / \mathrm{min}$ & $2884 \mathrm{~mL}$ \\
\hline $21 \mathrm{~L} / \mathrm{min}$ & $3250 \mathrm{~mL}$ & $21 \mathrm{~L} / \mathrm{min}$ & $3246 \mathrm{~mL}$ \\
\hline $21 \mathrm{~L} / \mathrm{min}$ & $3612 \mathrm{~mL}$ & $21 \mathrm{~L} / \mathrm{min}$ & $3608 \mathrm{~mL}$ \\
\hline
\end{tabular}

As can be seen in the Table 3, the water flow sensor work properly by tested simultaneously. There are some different values in the experiment caused by less tight of pipe joints which cause the water comes out from the pipe and give a different value of water flow sensor data.

B. Water leakage detection experiment with $25 \%$ water leak

This experiment is done by setting the water faucet in the $25 \%$ opened with the knob position in 22.5 degrees. The result of the experiment can be seen in the Table 4 .

Table 4. Water flow experiment with $25 \%$ water leak

\begin{tabular}{|c|c|c|}
\hline \multirow{2}{*}{ Time } & Sensor 1 (In) & Sensor 2 (Out) \\
\cline { 2 - 3 } & Water debit & Water debit \\
\hline $20: 58: 27.628$ & $23 \mathrm{~L} / \mathrm{min}$ & $17 \mathrm{~L} / \mathrm{min}$ \\
\hline $20: 58: 28.626$ & $23 \mathrm{~L} / \mathrm{min}$ & $17 \mathrm{~L} / \mathrm{min}$ \\
\hline $20: 58: 29.626$ & $23 \mathrm{~L} / \mathrm{min}$ & $17 \mathrm{~L} / \mathrm{min}$ \\
\hline $20: 58: 30.629$ & $23 \mathrm{~L} / \mathrm{min}$ & $17 \mathrm{~L} / \mathrm{min}$ \\
\hline $20: 58: 31.628$ & $23 \mathrm{~L} / \mathrm{min}$ & $17 \mathrm{~L} / \mathrm{min}$ \\
\hline $20: 58: 32.638$ & $23 \mathrm{~L} / \mathrm{min}$ & $17 \mathrm{~L} / \mathrm{min}$ \\
\hline $20: 58: 33.643$ & $23 \mathrm{~L} / \mathrm{min}$ & $17 \mathrm{~L} / \mathrm{min}$ \\
\hline $20: 58: 34.645$ & $23 \mathrm{~L} / \mathrm{min}$ & $17 \mathrm{~L} / \mathrm{min}$ \\
\hline $20: 58: 35.644$ & $23 \mathrm{~L} / \mathrm{min}$ & $17 \mathrm{~L} / \mathrm{min}$ \\
\hline $20: 58: 36.640$ & $23 \mathrm{~L} / \mathrm{min}$ & $17 \mathrm{~L} / \mathrm{min}$ \\
\hline
\end{tabular}

Table 4 present the data reading of the sensor during water flow with $25 \%$ water leak and time sampling for data reading is 1 second. As can be seen in sensor 2 output, there is differences between sensor 1 data which water debit through the sensor 1 is $23 \mathrm{~L} / \mathrm{min}$ and water debit through sensor 2 is $17 \mathrm{~L} / \mathrm{min}$. From the data above, the sensor detected a different value after water flow passes the leakage point.

\section{Water leakage detection experiment with $50 \%$ water leak}

This experiment set the water faucet in the $50 \%$ opened with the knob position in 45 degrees. The result of the experiment can be seen in the Table 5 with the sensor reading sampling time is set for 1 second. 
BEST

Journal of Applied Electrical \& Science Technology - University of PGRI Adi Buana

p-ISSN 2715-2871

e-ISSN 2714-5247

Table 5. Water flow experiment with $50 \%$ water leak

\begin{tabular}{|c|c|c|}
\hline \multirow{2}{*}{ Time } & Sensor 1 (In) & Sensor 2 (Out) \\
\cline { 2 - 3 } & Water debit & Water debit \\
\hline $21: 56: 40.487$ & $24 \mathrm{~L} / \mathrm{min}$ & $13 \mathrm{~L} / \mathrm{min}$ \\
\hline $21: 56: 41.500$ & $24 \mathrm{~L} / \mathrm{min}$ & $14 \mathrm{~L} / \mathrm{min}$ \\
\hline $21: 56: 42.499$ & $24 \mathrm{~L} / \mathrm{min}$ & $15 \mathrm{~L} / \mathrm{min}$ \\
\hline $21: 56: 43.501$ & $24 \mathrm{~L} / \mathrm{min}$ & $15 \mathrm{~L} / \mathrm{min}$ \\
\hline $21: 56: 44.500$ & $24 \mathrm{~L} / \mathrm{min}$ & $15 \mathrm{~L} / \mathrm{min}$ \\
\hline $21: 56: 45.502$ & $24 \mathrm{~L} / \mathrm{min}$ & $15 \mathrm{~L} / \mathrm{min}$ \\
\hline $21: 56: 46.509$ & $24 \mathrm{~L} / \mathrm{min}$ & $15 \mathrm{~L} / \mathrm{min}$ \\
\hline $21: 56: 47.477$ & $24 \mathrm{~L} / \mathrm{min}$ & $15 \mathrm{~L} / \mathrm{min}$ \\
\hline $21: 56: 48.480$ & $24 \mathrm{~L} / \mathrm{min}$ & $15 \mathrm{~L} / \mathrm{min}$ \\
\hline $21: 56: 49.480$ & $24 \mathrm{~L} / \mathrm{min}$ & $15 \mathrm{~L} / \mathrm{min}$ \\
\hline
\end{tabular}

\section{Water leakage detection experiment with $75 \%$ water leak}

This experiment set the water faucet in the $75 \%$ opened with the knob position in 67.5 degrees. The result of the experiment can be seen in the Table 6 with the sensor reading sampling time is set for 1 second.

Table 6. Water flow experiment with $75 \%$ water leak

\begin{tabular}{|c|c|c|}
\hline \multirow{2}{*}{ Time } & Sensor 1 (In) & Sensor 2 (Out) \\
\cline { 2 - 3 } & Water debit & Water debit \\
\hline $22: 00: 28.805$ & $25 \mathrm{~L} / \mathrm{min}$ & $8 \mathrm{~L} / \mathrm{min}$ \\
\hline $22: 00: 29.809$ & $25 \mathrm{~L} / \mathrm{min}$ & $9 \mathrm{~L} / \mathrm{min}$ \\
\hline $22: 00: 30.811$ & $25 \mathrm{~L} / \mathrm{min}$ & $9 \mathrm{~L} / \mathrm{min}$ \\
\hline $22: 00: 31.812$ & $25 \mathrm{~L} / \mathrm{min}$ & $9 \mathrm{~L} / \mathrm{min}$ \\
\hline $22: 00: 32.810$ & $25 \mathrm{~L} / \mathrm{min}$ & $9 \mathrm{~L} / \mathrm{min}$ \\
\hline $22: 00: 33.816$ & $25 \mathrm{~L} / \mathrm{min}$ & $9 \mathrm{~L} / \mathrm{min}$ \\
\hline $22: 00: 34.820$ & $25 \mathrm{~L} / \mathrm{min}$ & $9 \mathrm{~L} / \mathrm{min}$ \\
\hline $22: 00: 35.820$ & $25 \mathrm{~L} / \mathrm{min}$ & $9 \mathrm{~L} / \mathrm{min}$ \\
\hline $22: 00: 36.820$ & $25 \mathrm{~L} / \mathrm{min}$ & $9 \mathrm{~L} / \mathrm{min}$ \\
\hline $22: 00: 37.821$ & $25 \mathrm{~L} / \mathrm{min}$ & $9 \mathrm{~L} / \mathrm{min}$ \\
\hline
\end{tabular}

E. Water leakage detection experiment with $100 \%$ water leak

This experiment set the water faucet in the $100 \%$ opened with the knob position for about 90 degrees. The result of the experiment can be seen in the Table 7 with the sensor reading sampling time is set for 1 second.

Table 7. Water flow experiment with $100 \%$ water leak

\begin{tabular}{|c|c|c|}
\hline \multirow{2}{*}{ Time } & Sensor 1 (In) & Sensor 2 (Out) \\
\cline { 2 - 3 } & Water debit & Water debit \\
\hline $21: 56: 40.487$ & $24 \mathrm{~L} / \mathrm{min}$ & $13 \mathrm{~L} / \mathrm{min}$ \\
\hline $21: 56: 41.500$ & $24 \mathrm{~L} / \mathrm{min}$ & $14 \mathrm{~L} / \mathrm{min}$ \\
\hline $21: 56: 42.499$ & $24 \mathrm{~L} / \mathrm{min}$ & $15 \mathrm{~L} / \mathrm{min}$ \\
\hline $21: 56: 43.501$ & $24 \mathrm{~L} / \mathrm{min}$ & $15 \mathrm{~L} / \mathrm{min}$ \\
\hline $21: 56: 44.500$ & $24 \mathrm{~L} / \mathrm{min}$ & $15 \mathrm{~L} / \mathrm{min}$ \\
\hline $21: 56: 45.502$ & $24 \mathrm{~L} / \mathrm{min}$ & $15 \mathrm{~L} / \mathrm{min}$ \\
\hline $21: 56: 46.509$ & $24 \mathrm{~L} / \mathrm{min}$ & $15 \mathrm{~L} / \mathrm{min}$ \\
\hline $21: 56: 47.477$ & $24 \mathrm{~L} / \mathrm{min}$ & $15 \mathrm{~L} / \mathrm{min}$ \\
\hline $21: 56: 48.480$ & $24 \mathrm{~L} / \mathrm{min}$ & $15 \mathrm{~L} / \mathrm{min}$ \\
\hline $21: 56: 49.480$ & $24 \mathrm{~L} / \mathrm{min}$ & $15 \mathrm{~L} / \mathrm{min}$ \\
\hline
\end{tabular}

The experiment results of water leakage detection using water flow sensor given that the water leak detection work well where can be seen in the water flow sensor 2 data as the output can detect the different data of water debit input. The data will be used to send an information to the smartphone for the further action. The experiment of water leakage detection system and smartphone connectivity can be seen in the next chapter.

\section{Water leakage detection system smartphone notification experiment}

The goal of this experiment is the water leakage detection system can send a notification to the smartphone through the GSM module SIM800L that connected to the Arduino Uno. Arduino Uno will send texts to the smartphone to notify operator for the further action when water leak detected in the pipeline. The Arduino will send "Water leak detected" text when water flow sensor 1 and water flow sensor 2 give a different 
BEST

Journal of Applied Electrical \& Science Technology - University of PGRI Adi Buana

p-ISSN 2715-2871

e-ISSN 2714-5247

value. Result of the experiment can be seen in Figure 3.

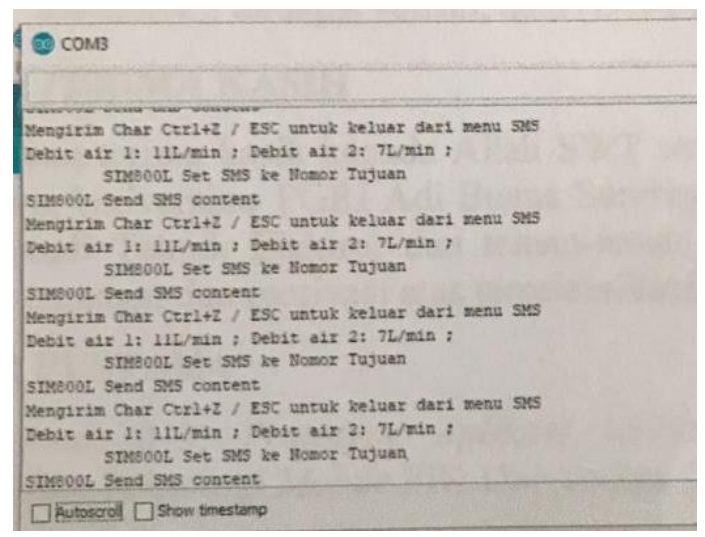

Figure 3. Send notification to smartphone

As can be seen in the Figure 3, Arduino Uno send an SMS notification to smartphone when water leak occurred. From the serial monitor can be seen that there is different value from sensor 1 and sensor 2 so, the SIM800L send the text to the smartphone with the phone number has been set before. The sent notification present in Figure 4 with "PIPA BOCOR" text it means water leak occurred.

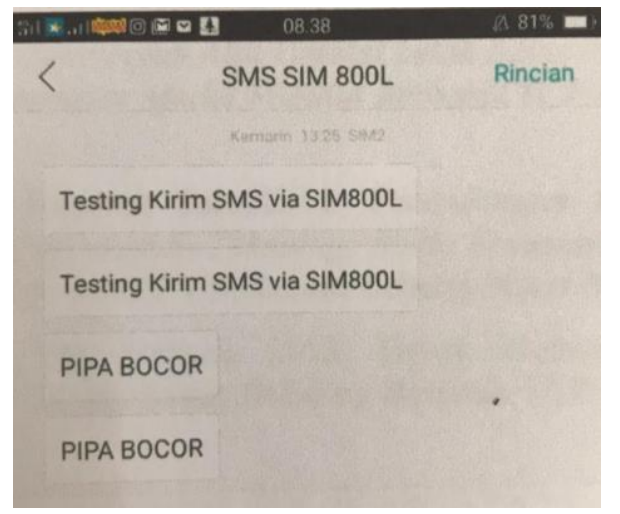

Figure 4. Water leak warning sent to smartphone

\section{CONCLUSION}

From the results of the experiments given conclusions about the water leakage detection system where the system has been tested and work properly. Water flow sensor detect a different value during water leak occurred. The system can send a notification to the smartphone if water leak occurred to give warning notification to the operator for the further technical actions. For further research, the system can be added an IoT method so it can be monitored from the internet, record the data and store the data to the cloud for documentation.

\section{ACKNOWLEDGMENT}

The researcher thanked to Allah SWT and all the Electrical Engineering Department who give support during the research as well as the Dean of the Faculty of Industrial Engineering and the Head of the Electrical Engineering Laboratory of PGRI Adi Buana Surabaya University who had provided facilities in this research process.

\section{REFERENCE}

[1] Affandi, Andi. 2013. Prototype Aplikasi MTicketing pada Penjualan Tiket Pesawat Menggunakan Teknologi Mobile. FIKUniversitas Dian Nuswantoro Semarang.

[2] Efendi, Hardi Anto. 2018. Sistem Otomatisasi Pengendali Lampu Gedung Bertingkat Berbasis Arduino dan Android Via Bluetooth dengan MIT Inventor. FTI Universias PGRI Adi Buana Surabaya.

[3] Hariyanto, Duwi. 2016. Perancangan Alat Deteksi Letak Kebocoran Pipa PVC Menggunakan Sensor Flowmeter Model FS300A Berbasis TCP/IP. FMIPA Universitas Lampung.

[4] Nugraha, Restu Buana Kusuma Sakti. 2011. Perancangan Prototype Sistem Informasi Pergudangan dengan Menggunakan Teknologi Radio Frequency Identification (RFID) di PT. Sriwahana Adityakarta Boyolali.FT Universitas Sebelas Maret Surakarta.

[5] Ng, Kiat Siong., Chen, Pei-Yin., Tseng, YuanChi. 2017. A Design of Automatic Water Leak Detection Device. $2017 \quad 2^{\text {nd }}$ International Conference on Opto-Electronic Information Processing. Taiwan.

[6] Uddin, Muhammad Arman., Hossain, Mohammad Mohibul., Ahmed, Akil., Sabuj, Hasibul Hasan., Samin, Seaum Yasar. 2019. Leakage Detection in Water Pipeline Using Microcontroller. $1^{\text {st }}$ International Conference on Advance in Science, Engineering and Robotics Technology 2019 (ICASERT 2019). IEEE. 